Published in final edited form as:

Rheum Dis Clin North Am. 2017 May ; 43(2): 287-302. doi:10.1016/j.rdc.2016.12.011.

\title{
Menopause and rheumatic disease
}

\author{
Mitali Talsania, MBBS ${ }^{1}$ and $\mathbf{R}$. Hal Scofield, $\mathbf{M D}^{1,2,3}$ \\ ${ }^{1}$ Section of Endocrinology, Diabetes and Metabolism, Department of Medicine, College of \\ Medicine, University of Oklahoma Health Sciences Center \\ ${ }^{2}$ Arthritis \& Clinical Immunology Program, Oklahoma Medical Research Foundation \\ ${ }^{3}$ Medical Service, Department of Veterans Affairs Medical Center, Oklahoma City, Oklahoma
}

\section{Abstract/Synopsis}

\begin{abstract}
Menopause occurs naturally in women at about age 50. There is a wealth of data concerning the relationship of menopause to systemic lupus erythematosus, rheumatoid arthritis and osteoarthritis, while there are limited data concerning other rheumatic diseases. Age at menopause may affect the risk and course of rheumatic diseases. Osteoporosis, an integral part of inflammatory rheumatic diseases, is made worse by menopause. Hormone replacement therapy has been studied and its effects are varied depending upon the disease and even different manifestations within the same disease. Cyclophosphamide can induce early menopause but there is underlying decreased ovarian reserve in rheumatic diseases.
\end{abstract}

\section{Keywords}

Menopause; systemic lupus erythematosus; osteoarthritis; rheumatoid arthritis

\section{Introduction}

Menopause is defined as cessation of menses retrospectively for 12 months without pathophysiological cause. However, age-related changes in ovarian function begin in the middle of the fourth decade of life with decreased ovarian follicles. Resultant changes in hypothalamic and pituitary hormones to compensate for the falling reserve of ovarian follicles maintain ovulation and fertility, sometimes for decades. The transition to the menopausal state demonstrates highly variable cyclic follicle development and ovulation, along with disrupted menstrual bleeding patterns ${ }^{1}$. The average at menopause is about 51 with later age of menopause correlating with longevity ${ }^{2-4}$.

\footnotetext{
Correspondence to: Hal Scofield, 825 NE $13^{\text {th }}$ Street, MS 24, Oklahoma City, OK 73104, Phone +14052717774 , Fax +1 405271 4110, hal-scofield@omrf.ouhsc.edu.

Publisher's Disclaimer: This is a PDF file of an unedited manuscript that has been accepted for publication. As a service to our customers we are providing this early version of the manuscript. The manuscript will undergo copyediting, typesetting, and review of the resulting proof before it is published in its final citable form. Please note that during the production process errors may be discovered which could affect the content, and all legal disclaimers that apply to the journal pertain.

Disclosures

The authors have nothing to disclose.
} 
Rheumatic illnesses include diseases with evidence of autoimmunity as well as the common, near ubiquitous, osteoarthritis. These diseases are generally more common among women compared to men. There are extensive data describing the relationship of some diseases with the menopausal state, while the data are scant for other rheumatic diseases. In this review, we will consider the impact of menopause on several of these diseases, and the reverse; that is, the impact of the diseases on menopause.

\section{Systemic Lupus Erythematosus (SLE)}

SLE is the prototype systemic inflammatory rheumatic disease. There is a wide range of serological and clinical manifestations attributed to SLE with virtually every patient having a unique disease course. The disease affects women about 10 times more commonly than men with onset typically in the third or fourth decade of life ${ }^{16}$. Despite the usual onset well prior to the average age of menopause, there is a wealth of data concerning menopause and SLE, with multiple aspects of this relationship to consider. Among these are whether age of onset of menopause is a risk factor for SLE, and whether onset of menopause alters the course or severity of the disease or its complications, including accelerated cardiovascular disease. Hormonal therapy for menopause may also interact with the disease. Disease with onset after menopause, while uncommon, may be a distinct entity compared to pre-menopausal onset. Finally, cytotoxic therapy of SLE may induce an iatrogenic and early menopause. This review will consider these aspects of SLE and menopause.

A recent cross-sectional study examined menopause in 961 SLE patients, of whom $7.9 \%$ had natural menopause ${ }^{17}$. Meanwhile, $4.1 \%$ had undergone a hysterectomy and $6.3 \%$ had menopause after taking cyclophosphamide. Only a small number $(0.1 \%)$ had menopause associated with end stage renal disease. The mean age at menopause was 46.4 years and the median age was 50.7 years, both similar to reported values for the general population ${ }^{17}$. An early age at menopause was associated with an earlier age of SLE diagnosis, however ${ }^{17}$. In LUMINA, a multi-ethnic SLE cohort from the USA, 37 of 316 woman had premature menopause. In a multivariable regression analysis, age at receiving cyclophosphamide, cyclophosphamide induction therapy, higher disease activity and Texas-Hispanic heritage were associated with a premature gonadal failure ${ }^{18}$. Older studies also show age and cumulative dose of the drug as important predictors of premature menopause ${ }^{19}$. Another study compared prolonged IV cyclophosphamide to 5-7 monthly doses followed by mycophenolate mofetil. In the latter group only 1 of 22 women (4\%) had sustained amenorrhea, while in patients with prolonged cyclophosphamide treatedment 20 of 39 $(51 \%)$ had sustained amenorrhea. Once again, older age at initiation of treatment was an important risk factor ${ }^{20}$. Neutrophil count suppression by pulse IV cyclophosphamide ${ }^{21}$ as well hypothyroidism ${ }^{22}$ may also predict premature ovarian failure. In the latter study, 11 of 71 SLE patients receiving cyclophosphamide developed ovarian failure:all $11 \mathrm{had}$ hypothyroidism as evidenced by an elevated $\mathrm{TSH}^{22}$. Thus, treatment with cyclophosphamide can induce premature menopause in women with SLE, especially when treatment begins at an older (>32 years) age, while hypothyroidism as a risk factor is reported but not confirmed by subsequent studies. 
Nonetheless, factors unrelated to cyclophosphamide can affect ovarian reserve in SLE patients. Using levels of anti-Muellerian hormone (AMH) as a measure of ovarian function in a study of 33 pre-menopausal SLE women (without past cyclophosphamide use) and 33 age and ethnicity matched healthy controls, Lawrenz and colleagues found lower mean AMH in SLE ( $2.15 \pm 1.64$ versus $3.17 \pm 2.29)$; however, there was no difference in number of pregnancies or spontaneous abortions between the groups ${ }^{23}$. Another study confirmed this result but found AMH levels did not predict early menopause ${ }^{24}$. The factors intrinsic to SLE that affect ovarian function and reserve have not yet been identified. And, while anti-ovarian antibodies have been described in SLE patients ${ }^{25}$, there is no evidence of premature menopause among SLE patients apart from the effects of cyclophosphamide ${ }^{26}$.

Pharmacological suppression of ovarian function by GnRH agonists may protect women from premature ovarian failure caused by this drug ${ }^{27,28}$, and there are several other strategies to preserve fertility after cyclophosphamide including oocyte preservation ${ }^{29}$.

Whether or not menopause, natural or otherwise, affects the course of SLE has been investigated. This includes study of SLE with onset at an older, post-menopausal age. A study of SLE with average age of onset at 55 years among 20 post-menopausal and 70 premenopausal women showed the post-menopausal women were statistically less likely to have malar rash (55\% versus $80 \%$ ), renal disease (30\% versus $69 \%)$, leukopenia ( $25 \%$ versus $56 \%$ ) or positive ANA ( $70 \%$ versus $93 \%)^{30}$. Other studies find low incidence of antidsDNA and hypocomplementemia among post-menopausal SLE onset ${ }^{31}$. Thus, absence of these characteristic features, along with the older age, may make diagnosis difficult.

Menopause may also affect the course of SLE. In a study of 34 post-menopausal SLE patients with pre-menopausal onset compared to SLE patients continuing to have menstrual periods, Mok and colleagues found fewer $(0.5 /$ year versus 0.14 / year) and less severe flares $^{32}$. Mean and maximum disease activity were both decreased in 30 SLE patients not receiving sex hormone therapy followed for an average of 1.7 years before and 3.3 years after menopause ${ }^{33}$.

Surgical menopause before SLE onset was associated with less renal involvement and lower anti-dsDNA seropositivity, an effect independent of ethnicity ${ }^{34}$. However, the Toronto Lupus Group have shown a constant rate of improvement in disease activity over time since diagnosis regardless of onset of menopause, concluding that menopause is not a proximate cause of improved SLE disease activity ${ }^{35}$. That is, the evidence suggests that SLE improves after menopause but a cause and effect relationship has not been established.

The relationship of menopause to disease activity in SLE begs the controversial question of whether post-menopausal sex hormone replacement is safe in SLE patients. This topic has been studied and reviewed extensively ${ }^{36,37}$. Evidence from the Nurses' Health Study, a large prospective cohort study, shows a 2-fold increased risk of SLE for women treated with postmenopausal hormone replacement ${ }^{38}$. However, these data were collected at a time when such therapy was much more common than at the present. Estrogen or combined estrogenprogesterone therapy ${ }^{39}$ is associated with increased mild to moderate flares of SLE, but not with severe flares ${ }^{37}$. New data is available that may suggest possible mechanisms of SLE flares with hormonal therapy. In a recent study of 35 SLE patients and 15 controls, 
investigators found increased expression of toll-like receptor (TLR)-3, -7 and 9 on peripheral blood mononuclear cells when comparing patients to controls. Post-menopausal status among the patients was associated with a higher percentage of cells expressing TLRs ${ }^{40}$. Another study reported decreased TNF production by estrogen-treated peripheral blood mononuclear cells from SLE patients ${ }^{41}$.

Menopause has been studied in relationship to complications of SLE, especially premature atherosclerosis and osteoporosis. Low bone density is associated with disease activity and damage accrual: osteoporosis is an intrinsic part of SLE that is not induced purely by treatment ${ }^{42}$. Menopause is a risk factor for more severe osteoporosis as well as fragility fracture. Post-menopausal SLE patients were significantly more likely to have a vertebral compression fracture than pre-menopausal patients ${ }^{43}$. Further, the 10 -year risk of osteoporotic fracture is greater among women with SLE compared to matched controls, despite comparable bone mineral density values. This risk was predicted by premature menopause as well as cumulative glucocorticoid dose $\mathrm{e}^{44}$. Treatment with either estrogen or selective estrogen agonists such as raloxifene ${ }^{45}$ maintain bone density in post-menopausal SLE patients. Newer data suggest that raloxifene does not worsen lupus flares, alter disease activity, or increase inflammatory markers in post-menopausal SLE patients ${ }^{46}$. But, the study is small $(\mathrm{n}=62)$ and relatively short $(12 \text { months })^{45}$.

Women with SLE have dramatically increased rates of cardiovascular disease such that beginning about 10 years after diagnosis this is the most common cause of death ${ }^{47}$. Interestingly, a correlate of premature cardiovascular disease, as measured by coronary artery calcification, is low bone mineral density ${ }^{48}$. There are a number of studies of vascular function, which may serve as a surrogate of vascular disease, in women with SLE. Pulse wave velocity measured at peripheral large arteries determines arterial elasticity. Postmenopausal SLE patients $(n=96)$ had worsened pulse wave velocity compared to premenopausal patients $(n=124)$ but most of this difference was explained by age in a multivariate analysis. But, higher cumulative organ damage and worsened renal function were associated with stiffer arteries in the post-menopausal group ${ }^{49}$. A more traditional measure of arterial function is flow- mediated dilatation, usually determined at the brachial artery. A meta-analysis of these studies found that while endothelium-dependent flow mediated dilatation was impaired in SLE patients, menopause was not an important determinate in multivariate analysis ${ }^{50}$.

\section{Rheumatoid Arthritis}

Rheumatoid arthritis affects about $1 \%$ of the worldwide population with a ratio of women to men of up to 6 to 1 in young adults ${ }^{52}$, but the sex ratio approaches 1 as age of onset increases ${ }^{53}$. The onset of disease is substantially older than that seen in SLE such that initial disease among women is commonly in post-menopausal years ${ }^{54}$. Extra-articular disease may rarely lead to life threatening complications, but RA patients have excess mortality from several causes including cardiovascular, infectious, and hematological disease $\mathrm{e}^{54}$. Similar to SLE and OA, there are multiple aspects of the disease potentially related to menopause. 
First among these to consider is whether menopause increases risk or severity of RA. In fact, the results of observational studies of both menopause and estrogenic hormones, either postmenopausal or contraception, are variable and discrepant ${ }^{55,56}$. A study from Belgium showed that first symptoms of RA had a mean time from onset of menopause of zero. The authors suggested these data indicate that the average women with RA has the onset of symptoms concurrent with menopause ${ }^{53}$. A recent study showed that menopause prior to age 45 (early menopause) was associated with milder RA ${ }^{57}$. Meanwhile, another study found early menopause was associated with post-menopausal onset of RA ${ }^{58}$. Thus, a definite conclusion about the effects of menopause on RA cannot be made.

Some observational studies, but not all, show hormone replacement therapy (HRT) or oral contraception improves disease among post-menopausal women ${ }^{56,61-69}$. Similar to cardiovascular disease risk of HRT, studies of RA risk may be confounded by use of estrogen alone versus estrogen plus progesterone. A recent population-based epidemiologic study from Sweden showed a decreased risk of anti-CCP positive RA among postmenopausal women over age 50 with most of this reduction occurring in women on combination HRT, (odds Ratio 0.3$)^{66}$. But, in a 2 year study of HRT in 88 post-menopausal women with RA, there were no changes in autoantibodies ${ }^{70}$. In addition, a 6-month, randomized, single-blinded, placebo-controlled trial showed no improvement in RA ${ }^{71}$. But, the latter trial likely has no bearing on whether or not HRT reduces the risk of developing RA.

Similar to other inflammatory rheumatic illnesses, osteoporosis is caused in part by the disease itself with specific effects on bone remodeling an not simply a result of glucocorticoid therapy ${ }^{72}$. In a study of 343 post-menopausal and 100 pre-menopausal women with RA, $56 \%$ of the former but only $18 \%$ of the latter had osteoporosis ${ }^{73}$. Of course, study of healthy women before and after menopause might find similar numbers. However, there is clearly excess osteoporosis among RA women compared to controls with post-menopausal status an important predictor ${ }^{74}$. Excess bone loss seen in RA occurs early in the disease $\mathrm{e}^{75}$. Recent studies from the era of biologics (and low prevalence of postmenopausal HRT) continue to show excess osteoporosis in RA patients compared to agematched controls (30\% versus $17.4 \%$ ), and an association with menopause ${ }^{76}$. HRT reduces bone resorption regardless of glucocorticoid therapy in post-menopausal RA patients ${ }^{77,78}$, but there are, of course, other potential health concerns with post-menopausal HRT.

\section{Osteoarthritis}

Osteoarthritis (OA) is highly prevalent in postmenopausal women. The Women's Health Initiative showed that $44 \%$ of the participating postmenopausal women reported OA. Risk factors in this study include higher BMI and older age. American Indian and African American women in the extreme obesity category have significant odds of OA compared to non-Hispanic white women ${ }^{86}$.

Estrogen receptors are present in joint tissues. Estrogen has chondro-protective roles in part due to glycosaminoglycan synthesis, which is an important part of connective tissue.

Estrogen also inhibits cyclooxygenase 2 mRNA expression in bovine articular chondrocytes 
as well as other tissues, leading to protection against reactive oxygen species induced chondrocyte damage ${ }^{92}$. Estrogens decrease cartilage damage. Conincubation of chonodrocytes with IL-1b and raloxifene led to dose dependent increase in proteoglycans and reduction of MMP-3 and nitric oxide induced by $\mathrm{IL}-1 \mathrm{~B}^{93}$. Polymorphism in the estrogen receptor (ER) alpha gene may be associated with risk of severe OA of large, lower limb joints in a sex specific manner suggesting that estrogen activity may influence the development of large joint $\mathrm{OA}^{94}$. The same study concluded that variation in aromatase gene CYP19A1 and ER alpha gene, are associated with risk of severe OA. Influence of the CYP19A1 single nucleotide polymorphism is more important in women than in men, and in knee OA than in hip $\mathrm{OA}^{94}$. Recent meta-analysis by Gong, et al. reported rs 9340799 and rs2228480 polymorphisms, rather than the rs 2234693 polymorphism, in estrogen receptor alpha gene are associated with the incidence of $\mathrm{OA}^{95}$.

It has been demonstrated that CTX II, marker of collagen degradation, increases in the urine of asymptomatic postmenopausal women and ovarectomized rats, suggesting that estrogen deprivation leads to cartilage breakdown. No association has been found for urinary Helix II and estrogen deprivation leading to cartilage breakdown ${ }^{96}$. Study of 860 women in China noted that menopause is associated with cartilage degeneration of knee joint compared to pre and peri-menopausal women. Knee cartilage showed progressive severe degeneration on MRI in the first 2.5 years since menopause. However, while the authors reported controlling for age, the study did not achieve much overlap in age across the menopause status group. The authors concluded that estrogen deficiency is a risk factor for cartilage degeneration and further studies are needed to clarify whether age or menopause plays a more important role in progression of cartilage degeneration ${ }^{97}$. The study could not definitely differentiate between the effects of menopause and age in our opinion.

Chen, et al. studied endogenous estrogens and estrogen metabolites in pre and postmenopausal Chinese women with osteoarthritis. The study showed that serum concentration of free estradiol and total 2-hydroxyestrone were significantly lower in premenopausal women with OA compared to the levels in controls (RA and healthy women). In post-menopausal women, serum concentration of free and total estradiol was significantly decreased compared to controls. 2-hydroxyestradiol was significantly increased in post-menopausal women. The authors reported that apart from free and total estradiol deficiency, decreased serum level of total 2-hydroxyestrone in premenopausal women and increased total 2-hydroxyestradiol level in post-menopausal women with OA may correlate with pathogenesis of $\mathrm{OA}^{100,101}$.

Studies on hormonal therapy in post-menopausal women with osteoarthritis have shown conflicting evidence (Table 1). Women's Health Initiative study showed that there are 29\% greater odds of OA with past HRT use and 38\% greater odds of OA for current HRT. American Indian women who reported current HRT use had an odds ratio of $>2$ for arthritis (presumably OA) than the population as a whole ${ }^{86}$. In contrast, an Italian study showed HRT is associated with $27 \%$ lower odd ratio of physician diagnosed $\mathrm{OA}^{102}$. A cohort study of 1001 post-menopausal women (mean age 71 years) examined effect of post-menopausal estrogen therapy on hand, knee and hip osteoarthritis. 638 women had used estrogen postmenopause for greater than one year, $71 \%$ were current users. Post-menopausal estrogen use 
for greater than one year was associated with higher prevalence of OA compared to no use of estrogen ( $34.5 \%$ compared to $30.9 \%, \mathrm{p}=0.02$ ). Women using estrogen had significantly higher prevalence of hip and hand OA $(15.8 \%$ vs $13.5 \%, \mathrm{p}=0.02$ for hip, $4.1 \%$ compared to $1.1 \%, \mathrm{p}=0.002$ for hand). Knee OA was slightly higher with estrogen use; however, the difference was not statistically significant. Unfortunately, this study did not report radiographic evidence of $\mathrm{OA}^{103}$. In contrast, a large cross sectional study evaluated 4,366 post-menopausal women for osteoporotic fractures. Women currently using estrogen had $40 \%$ lower prevalence of radiologic and symptomatic hip OA. Reduction was greater for estrogen use $>10$ years ${ }^{104}$. In the Framingham OA study, estrogen use was not associated with increased risk of radiographic osteoarthritis of the knees. In fact, estrogen use had a modest but non-significant protective effect in the study ${ }^{105}$. In heart and estrogen/progestin replacement study, older postmenopausal women with cardiac disease $(n=969)$ were assessed for knee pain. There was no significant effect of 4 years of estrogen plus progestin therapy compared to placebo on knee pain and related disability, indicating that HRT is not associated with more prevalent or severe knee pain ${ }^{106}$.The Chingford cross-sectional study demonstrated an inverse association of current post-menopausal HRT use and radiologic knee OA, suggesting protective effects. There was a non-significant protective effect for distal interphalangeal OA, but no clear effect on carpometacarpal joints, leading to the conclusion that effect was weaker in the hand joints ${ }^{107}$. Further studies are needed to evaluate true effect of estrogen replacement on the OA considering the current contradictory evidence. Consideration of the site of OA may be critical in any such study.

The effect of hormone therapy on risk of hip and knee joint replacement was evaluated in the Women's Health Initiative study. The population included post-menopausal women aged 50-79 who were followed for a mean of 7.1 years. Women who had had hysterectomies $(n=10,272)$ were randomly assigned to received $0.625 \mathrm{mg}$ per day of conjugated equine estrogen or placebo. Those with an intact uterus $(n=16,049)$ were randomly assigned to receive estrogen (conjugated equine estrogen $0.625 \mathrm{mg}$ ) and progestin (medroxyprogesterone acetate $2.5 \mathrm{mg} / \mathrm{d}$ ) vs placebo. Women receiving estrogen alone had significantly lower rates of arthroplasty (HR 0.84, 95\%CI: 0.70-1.00). This effect had only borderline significance for hip arthroplasty (HR 0.73, 95\%CI: 0.52-1.03), and was not significant for knee arthroplasty. In the estrogen and progestin trial, there was no association for total, hip, or knee arthroplasty ${ }^{108}$. In a recent prospective study of 2,621 women greater estradiol concentration was associated with lower incidence of knee replacement (HR 0.70 , 95\%CI: 0.50-0.96). Lower androstenedione concentration and higher sex hormone binding protein concentration were associated with higher incidence of knee replacement (HR 1.7, 95\% CI 1.05-2.77) ${ }^{109}$. Estrogen appears to have a protective effect on joint replacement, specifically on the hip more than knee; however, this effect is negated by presence of progestin. Further studies are needed to clarify the role of estrogen after menopause on mitigating OA.

\section{Sjögren's Syndrome}

Primary Sjögren's syndrome has a marked bias towards women with at least a 10:1 ratio to men, but generally has its onset late in life, frequently in post-menopausal years ${ }^{110}$. Nonetheless, menopause and its effects on this disease are little studied. Postmenopausal as 
well as pre-menopausal women with Sjögren's syndrome have increased vaginal dryness and dyspareunia ${ }^{111}$ as well as decreased quality of sexual life compared to controls ${ }^{112}$. The decrease was related to multiple factors, including dyspareunia, lubrication, desire and arousal according to the Female Sexual Function Index ${ }^{112}$.

Sex hormone levels have been studies minimally compared other rheumatic illness. One small study of 17 Sjögren's patients and 19 healthy controls showed statistically significantly higher prolactin levels among the patients (11.4 versus $6.7 \mathrm{ng} / \mathrm{ml})$, while there were no statistical differences of estrogen or progesterone levels ${ }^{113}$. There is an aspect of sex hormone metabolism that could be affected uniquely by Sjögren's syndrome among the rheumatic illnesses. Dehydroepiandrosterone-sulfate (DHEAS) is produced in the adrenal glands of estrogen-deficient women and is converted into dehydroepiandrosterone in exocrine glands. This latter metabolism may be abnormal as a result of Sjögren's pathology in these glands resulting in immune effects ${ }^{114,115}$. Trials of dehydroepiandrosterone in Sjögren's syndrome have failed to show benefit for fatigue or salivary flow even among patients with low serum levels ${ }^{116-118}$. Perhaps these negative trials were the result of failure to convert DHEAS in exocrine gland tissue.

\section{Scleroderma}

Systemic sclerosis (SSc) is a disorder characterized by vascular damage, overproduction of collagen and its deposition and other matrix constituents into skin and internal organs ${ }^{119}$. Estrogens have a protective role on arterial endothelium ${ }^{119}$. Postmenopausal SSc patients have lower level of testosterone, DHEAS and androstenedione compared to controls. There is a negative correlation between androstenedione and anti-centromere antibodies (ACA) levels. It was postulated that ACA is generally present in localized SSc and higher level of hormones suppress the autoimmune process in the skin and synthesis of ACA. Surprisingly, the same study has shown a positive correlation between Scl-70 antibodies and androgen levels ${ }^{120}$.

Menopause has effects on skin thickening, especially in diffuse SSc patients.

Postmenopausal women with diffuse SSc have lower mean modified Rodnan skin scores compared to pre-menopausal status women. The effect was smaller, but statistically significant, in limited SSc patients ${ }^{121}$.

In contrast to the skin, post-menopausal status is a risk factor for developing pulmonary hypertension. In the study by Scorza et al., 93 patients (49.2\%) were post-menopausal and $49(31.2 \%)$ were fertile. The cumulative probability of pulmonary hypertension increased over time in post-menopausal women compared to fertile women. Mean free interval time for pulmonary hypertension was 10.6 years in post-menopausal subjects compared to 20 years in fertile subjects $(\mathrm{p}<0.003)$. Relative risk of menopause for pulmonary hypertension was 5.2 with $p$ value of $<0.0001$. The mechanism underlying this effect was postulated as a lack of estrogen leading to decrease in nitrous oxide production and endothelial damage ${ }^{119}$. One retrospective study found that HRT soon after menopause has shown to be beneficial in preventing pulmonary hypertension in patients with limited SSc. However, the study was 
retrospective and the duration of hormone therapy was not defined. Randomized controlled trials are required to draw definitive conclusions ${ }^{122}$.

Post-menopausal women with SSc have higher prevalence of osteoporosis (42.7\%) compared to controls (10.7\%), with significant alteration in trabecular bone component in SSc patients. The presence of ACA was associated with lower bone mineral density in the same study. Digital ulceration was associated with lower total hip and femoral neck bone density ${ }^{123}$. Another study pointed out that earlier onset of menopause in SSc patients is associated with lower bone mineral density ${ }^{124}$.

\section{Summary}

Menopause interacts with rheumatic disease in various ways. For example, SLE with onset after menopause is generally milder, while menopause is a risk factor for pulmonary hypertension in SSc. The data concerning the relationship of menopause and rheumatic diseases are incomplete or contradictory in many cases. Osteoporosis is a part of many of these diseases and risk for this complication is increased by menopause. In SLE, treatment with cyclophosphamide can cause premature menopause, especially in women over 30 , who have decreased ovarian reserve. Treatment of menopause with hormone therapy has differential effects depending upon the disease and the manifestation examined.

\section{References}

1. Hall JE. Endocrinology of the Menopause. Endocrinol. Metab. Clin. North Am. 2015; 44(3):485496. [PubMed: 26316238]

2. Daan NM, Fauser BC. Menopause prediction and potential implications. Maturitas. 2015; 82(3): 257-265. [PubMed: 26278873]

3. Perls TT, Fretts RC. The evolution of menopause and human life span. Ann. Hum. Biol. 2001; 28(3):237-245. [PubMed: 11393331]

4. Perls TT, Alpert L, Fretts RC. Middle-aged mothers live longer. Nature. 1997; 389(6647):133.

5. Sievert LL. Anthropology and the study of menopause: evolutionary, developmental, and comparative perspectives. Menopause. 2014; 21(10):1151-1159. [PubMed: 25232712]

6. Peccei JS. A hypothesis for the origin and evolution of menopause. Maturitas. 1995; 21(2):83-89. [PubMed: 7752954]

7. Peccei JS. A critique of the grandmother hypotheses: old and new. Am. J. Hum. Biol. 2001; 13(4): 434-452. [PubMed: 11400215]

8. Kuhle BX. An evolutionary perspective on the origin and ontogeny of menopause. Maturitas. 2007; 57(4):329-337. [PubMed: 17544235]

9. Lahdenpera M, Lummaa V, Russell AF. Menopause: why does fertility end before life? Climacteric. 2004; 7(4):327-331. discussion 331-322. [PubMed: 15799603]

10. Lahdenpera M, Russell AF, Tremblay M, Lummaa V. Selection on menopause in two premodern human populations: no evidence for the Mother Hypothesis. Evolution. 2011; 65(2):476-489. [PubMed: 20874739]

11. Lahdenpera M, Gillespie DO, Lummaa V, Russell AF. Severe intergenerational reproductive conflict and the evolution of menopause. Ecol. Lett. 2012; 15(11):1283-1290. [PubMed: 22913671]

12. Penn DJ, Smith KR. Differential fitness costs of reproduction between the sexes. Proc. Natl. Acad. Sci. U. S. A. 2007; 104(2):553-558. [PubMed: 17192400] 
13. Shanley DP, Sear R, Mace R, Kirkwood TB. Testing evolutionary theories of menopause. Proceedings of the Royal Society of London - Series B: Biological Sciences. 2007; 274(1628): 2943-2949. [PubMed: 17878141]

14. Brent LJ, Franks DW, Foster EA, Balcomb KC, Cant MA, Croft DP. Ecological knowledge, leadership, and the evolution of menopause in killer whales. Curr. Biol. 2015; 25(6):746-750. [PubMed: 25754636]

15. Johnstone RA, Cant MA. The evolution of menopause in cetaceans and humans: the role of demography. Proceedings of the Royal Society of London - Series B: Biological Sciences. 2010; 277(1701):3765-3771. [PubMed: 20591868]

16. Borchers AT, Naguwa SM, Shoenfeld Y, Gershwin ME. The geoepidemiology of systemic lupus erythematosus. Autoimmunity Reviews. 2010; 9(5):A277-A287. [PubMed: 20036343]

17. Alpizar-Rodriguez D, Romero-Diaz J, Sanchez-Guerrero J, Seuc AH, Cravioto Mdel C. Age at natural menopause among patients with systemic lupus erythematosus. Rheumatology (Oxford). 2014; 53(11):2023-2029. [PubMed: 24907155]

18. Gonzalez LA, Pons-Estel GJ, Zhang JS, et al. Effect of age, menopause and cyclophosphamide use on damage accrual in systemic lupus erythematosus patients from LUMINA, a multiethnic US cohort (LUMINA LXIII). Lupus. 2009; 18(2):184-186. [PubMed: 19151125]

19. Ioannidis JP, Katsifis GE, Tzioufas AG, Moutsopoulos HM. Predictors of sustained amenorrhea from pulsed intravenous cyclophosphamide in premenopausal women with systemic lupus erythematosus. J. Rheumatol. 2002; 29(10):2129-2135. [PubMed: 12375322]

20. Laskari K, Zintzaras E, Tzioufas AG. Ovarian function is preserved in women with severe systemic lupus erythematosus after a 6-month course of cyclophosphamide followed by mycophenolate mofetil. Clin. Exp. Rheumatol. 2010; 28(1):83-86. [PubMed: 20346244]

21. McDermott EM, Powell RJ. Incidence of ovarian failure in systemic lupus erythematosus after treatment with pulse cyclophosphamide. Ann. Rheum. Dis. 1996; 55(4):224-229. [PubMed: 8733438]

22. Medeiros MM, Silveira VA, Menezes AP, Carvalho RC. Risk factors for ovarian failure in patients with systemic lupus erythematosus. Braz. J. Med. Biol. Res. 2001; 34(12):1561-1568. [PubMed: 11717709]

23. Lawrenz B, Henes J, Henes M, et al. Impact of systemic lupus erythematosus on ovarian reserve in premenopausal women: evaluation by using anti-Muellerian hormone. Lupus. 2011; 20(11):11931197. [PubMed: 21768179]

24. Morel N, Bachelot A, Chakhtoura Z, et al. Study of Anti-Mullerian Hormone and Its Relation to the Subsequent Probability of Pregnancy in 112 Patients With Systemic Lupus Erythematosus, Exposed or Not to Cyclophosphamide. J. Clin. Endocrinol. Metab. 2013 Sep; 98(9):3785-3792. [PubMed: 23833039]

25. Pasoto SG, Viana VS, Mendonca BB, Yoshinari NH, Bonfa E. Anti-corpus luteum antibody: a novel serological marker for ovarian dysfunction in systemic lupus erythematosus? J. Rheumatol. 1999; 26(5):1087-1093. [PubMed: 10332973]

26. Mayorga J, Alpizar-Rodriguez D, Prieto-Padilla J, Romero-Diaz J, Cravioto MC. Prevalence of premature ovarian failure in patients with systemic lupus erythematosus. Lupus. $2016 \mathrm{Jun} ; 25$ (7): 675-683. [PubMed: 26678443]

27. Marder W, McCune WJ, Wang L, et al. Adjunctive GnRH-a treatment attenuates depletion of ovarian reserve associated with cyclophosphamide therapy in premenopausal SLE patients. Gynecol. Endocrinol. 2012; 28(8):624-627. [PubMed: 22296584]

28. Brunner HI, Silva CA, Reiff A, et al. Randomized, double-blind, dose-escalation trial of triptorelin for ovary protection in childhood-onset systemic lupus erythematosus. Arthritis \& Rheumatology. 2015; 67(5):1377-1385. [PubMed: 25676588]

29. Oktem O, Guzel Y, Aksoy S, Aydin E, Urman B. Ovarian function and reproductive outcomes of female patients with systemic lupus erythematosus and the strategies to preserve their fertility. Obstet. Gynecol. Surv. 2015; 70(3):196-210. [PubMed: 25769434]

30. Deng XL, Liu XY. Less disease severity and favorable prognosis are associated with postmenopausal systemic lupus erythematosus patients. Rheumatol. Int. 2009; 29(5):535-538. [PubMed: 18813929] 
31. Lazaro D. Elderly-onset systemic lupus erythematosus: prevalence, clinical course and treatment. Drugs Aging. 2007; 24(9):701-715. [PubMed: 17727302]

32. Mok CC, Lau CS, Ho CT, Wong RW. Do flares of systemic lupus erythematosus decline after menopause? Scand. J. Rheumatol. 1999; 28(6):357-362. [PubMed: 10665741]

33. Sanchez-Guerrero J, Villegas A, Mendoza-Fuentes A, Romero-Diaz J, Moreno-Coutino G, Cravioto MC. Disease activity during the premenopausal and postmenopausal periods in women with systemic lupus erythematosus. Am. J. Med. 2001; 111(6):464-468. [PubMed: 11690572]

34. Namjou B, Scofield RH, Kelly JA, et al. The effects of previous hysterectomy on lupus. Lupus. 2009; 18(11):1000-1005. [PubMed: 19762402]

35. Urowitz MB, Ibanez D, Jerome D, Gladman DD. The effect of menopause on disease activity in systemic lupus erythematosus. J. Rheumatol. 2006; 33(11):2192-2198. [PubMed: 16981295]

36. Rojas-Villarraga A, Torres-Gonzalez JV, Ruiz-Sternberg AM. Safety of hormonal replacement therapy and oral contraceptives in systemic lupus erythematosus: a systematic review and metaanalysis. PLoS ONE [Electronic Resource]. 2014; 9(8):e104303.

37. Khafagy AM, Stewart KI, Christianson MS, Tao Y, Blanck JF, Shen W. Effect of menopause hormone therapy on disease progression in systemic lupus erythematosus: A systematic review. Maturitas. 2015; 81(2):276-281. [PubMed: 25882762]

38. Sanchez-Guerrero J, Liang MH, Karlson EW, Hunter DJ, Colditz GA. Postmenopausal estrogen therapy and the risk for developing systemic lupus erythematosus. Ann. Intern. Med. 1995; 122(6): 430-433. [PubMed: 7856991]

39. Buyon JP, Petri MA, Kim MY, et al. The effect of combined estrogen and progesterone hormone replacement therapy on disease activity in systemic lupus erythematosus: a randomized trial. Ann. Intern. Med. 2005; 142(12 Pt 1):953-962. [Summary for patients in Ann Intern Med. 2005 Jun 21;142(12 Pt 1):I22; PMID: 15968006]. [PubMed: 15968009]

40. Klonowska-Szymczyk A, Wolska A, Robak T, Cebula-Obrzut B, Smolewski P, Robak E. Expression of toll-like receptors 3, 7, and 9 in peripheral blood mononuclear cells from patients with systemic lupus erythematosus. Mediators Inflamm. 2014; 2014:381418. [PubMed: 24692849]

41. Evans MJ, MacLaughlin S, Marvin RD, Abdou NI. Estrogen decreases in vitro apoptosis of peripheral blood mononuclear cells from women with normal menstrual cycles and decreases TNF-alpha production in SLE but not in normal cultures. Clin. Immunol. Immunopathol. 1997; 82(3):258-262. [PubMed: 9073549]

42. Lee C, Almagor O, Dunlop DD, et al. Disease damage and low bone mineral density: an analysis of women with systemic lupus erythematosus ever and never receiving corticosteroids. Rheumatology (Oxford). 2006; 45(1):53-60. [PubMed: 16278288]

43. Mendoza-Pinto C, Garcia-Carrasco M, Sandoval-Cruz H, et al. Risk factors of vertebral fractures in women with systemic lupus erythematosus. Clin. Rheumatol. 2009; 28(5):579-585. [PubMed: 19224131]

44. Mak A, Lim JQ, Liu Y, Cheak AA, Ho RC. Significantly higher estimated 10-year probability of fracture in lupus patients with bone mineral density comparable to that of healthy individuals. Rheumatol. Int. 2013; 33(2):299-307. [PubMed: 22441963]

45. Mok CC, To CH, Mak A, Ma KM. Raloxifene for postmenopausal women with systemic lupus erythematosus: a pilot randomized controlled study. Arthritis Rheum. 2005; 52(12):3997-4002. [PubMed: 16320346]

46. Mok CC, Ying SK, Ma KM, Wong CK. Effect of raloxifene on disease activity and vascular biomarkers in patients with systemic lupus erythematosus: subgroup analysis of a double-blind randomized controlled trial. Lupus. 2013; 22(14):1470-1478. [PubMed: 24113197]

47. Ward MM, Pyun E, Studenski S. Long-term survival in systemic lupus erythematosus. Patient characteristics associated with poorer outcomes. Arthritis Rheum. 1995 Feb; 38(2):274-283. [PubMed: 7848319]

48. Ribeiro GG, Bonfa E, Sasdeli Neto R, et al. Premature coronary artery calcification is associated with disease duration and bone mineral density in young female systemic lupus erythematosus patients. Lupus. 2010; 19(1):27-33. [PubMed: 19933722]

49. Selzer F, Sutton-Tyrrell K, Fitzgerald S, Tracy R, Kuller L, Manzi S. Vascular stiffness in women with systemic lupus erythematosus. Hypertension. 2001; 37(4):1075-1082. [PubMed: 11304506] 
50. Mak A, Liu Y, Ho RC. Endothelium-dependent but not endothelium-independent flow-mediated dilation is significantly reduced in patients with systemic lupus erythematosus without vascular events: a metaanalysis and metaregression. J. Rheumatol. 2011; 38(7):1296-1303. [PubMed: 21459950]

51. Santos MJ, Pedro LM, Canhao H, et al. Hemorheological parameters are related to subclinical atherosclerosis in systemic lupus erythematosus and rheumatoid arthritis patients. Atherosclerosis. 2011; 219(2):821-826. [PubMed: 21906736]

52. Barragan-Martinez C, Amaya-Amaya J, Pineda-Tamayo R, et al. Gender differences in LatinAmerican patients with rheumatoid arthritis. Gend. Med. 2012; 9(6):490.e495-510.e495. [PubMed: 23217568]

53. Goemaere S, Ackerman C, Goethals K, et al. Onset of symptoms of rheumatoid arthritis in relation to age, sex and menopausal transition. J. Rheumatol. 1990; 17(12):1620-1622. [PubMed: 2084234]

54. Gabriel SE. The epidemiology of rheumatoid arthritis. Rheum. Dis. Clin. North Am. 2001; 27(2): 269-281. [PubMed: 11396092]

55. Carette S, Marcoux S, Gingras S. Postmenopausal hormones and the incidence of rheumatoid arthritis. J. Rheumatol. 1989; 16(7):911-913. [PubMed: 2769663]

56. Linos A, Worthington JW, O'Fallon WM, Kurland LT. Case-control study of rheumatoid arthritis and prior use of oral contraceptives. Lancet. 1983; 1(8337):1299-1300. [PubMed: 6134094]

57. Pikwer M, Nilsson JA, Bergstrom U, Jacobsson LT, Turesson C. Early menopause and severity of rheumatoid arthritis in women older than 45 years. Arthritis Res. Ther. 2012; 14(4):R190. [PubMed: 22901865]

58. Beydoun HA, el-Amin R, McNeal M, Perry C, Archer DF. Reproductive history and postmenopausal rheumatoid arthritis among women 60 years or older: Third National Health and Nutrition Examination Survey. Menopause. 2013; 20(9):930-935. [PubMed: 23942247]

59. Criswell LA, Merlino LA, Cerhan JR, et al. Cigarette smoking and the risk of rheumatoid arthritis among postmenopausal women: results from the Iowa Women's Health Study. Am. J. Med. 2002; 112(6):465-471. [PubMed: 11959057]

60. Krishnan E, Sokka T, Hannonen P. Smoking-gender interaction and risk for rheumatoid arthritis. Arthritis Res. Ther. 2003; 5(3):R158-R162. [PubMed: 12723987]

61. Hernandez-Avila M, Liang MH, Willett WC, et al. Oral contraceptives, replacement oestrogens and the risk of rheumatoid arthritis. Br. J. Rheumatol. 1989; 28(Suppl 1):31. discussion 42-35.

62. Hazes JM, Dijkmans BC, Vandenbroucke JP, de Vries RR, Cats A. Reduction of the risk of rheumatoid arthritis among women who take oral contraceptives. Arthritis Rheum. 1990; 33(2): 173-179. [PubMed: 2306289]

63. Linos A, Kaklamanis E, Kontomerkos A, Vagiopoulos G, Tjonou A, Kaklamanis P. Rheumatoid arthritis and oral contraceptives in the Greek female population: a case-control study. Br. J. Rheumatol. 1989; 28(Suppl 1):37. discussion 42-35. [PubMed: 2819350]

64. Vandenbroucke JP, Witteman JC, Valkenburg HA, et al. Noncontraceptive hormones and rheumatoid arthritis in perimenopausal and postmenopausal women. JAMA. 1986; 255(10):12991303. [PubMed: 3944948]

65. Koepsell TD, Dugowson CE, Nelson JL, Voigt LF, Daling JR. Non-contraceptive hormones and the risk of rheumatoid arthritis in menopausal women. Int. J. Epidemiol. 1994; 23(6):1248-1255. [PubMed: 7721528]

66. Orellana C, Saevarsdottir S, Klareskog L, Karlson EW, Alfredsson L, Bengtsson C. Postmenopausal hormone therapy and the risk of rheumatoid arthritis: results from the Swedish EIRA population-based case-control study. Eur. J. Epidemiol. 2015; 30(5):449-457. [PubMed: 25762170]

67. Wluka AE, Cicuttini FM, Spector TD. Menopause, oestrogens and arthritis. Maturitas. 2000; 35(3): 183-199. [PubMed: 10936736]

68. Salliot C, Bombardier C, Saraux A, Combe B, Dougados M. Hormonal replacement therapy may reduce the risk for RA in women with early arthritis who carry HLA-DRB1 01 and/or 04 alleles by protecting against the production of anti-CCP: results from the ESPOIR cohort. Ann. Rheum. Dis. 2010; 69(9):1683-1686. [PubMed: 19740903] 
69. Islander U, Jochems C, Lagerquist MK, Forsblad-d'Elia H, Carlsten H. Estrogens in rheumatoid arthritis; the immune system and bone. Mol. Cell. Endocrinol. 2011; 335(1):14-29. [PubMed: 20685609]

70. d'Elia HF, Carlsten H. The impact of hormone replacement therapy on humoral and cell-mediated immune responses in vivo in post-menopausal women with rheumatoid arthritis. Scand. J. Immunol. 2008; 68(6):661-667. [PubMed: 19086108]

71. Hall GM, Daniels M, Huskisson EC, Spector TD. A randomised controlled trial of the effect of hormone replacement therapy on disease activity in postmenopausal rheumatoid arthritis. Ann. Rheum. Dis. 1994; 53(2):112-116. [PubMed: 8129455]

72. Aeberli D, Schett G. Cortical remodeling during menopause, rheumatoid arthritis, glucocoticoid and bisphosphonate therapy. Arthritis Res. Ther. 2013; 15(2):208. [PubMed: 23521873]

73. Oelzner P, Schwabe A, Lehmann G, et al. Significance of risk factors for osteoporosis is dependent on gender and menopause in rheumatoid arthritis. Rheumatol. Int. 2008; 28(11):1143-1150. [PubMed: 18446340]

74. Lee SG, Park YE, Park SH, et al. Increased frequency of osteoporosis and BMD below the expected range for age among South Korean women with rheumatoid arthritis. Int. J. Rheum. Dis. 2012; 15(3):289-296. [PubMed: 22709491]

75. Kroot EJ, Nieuwenhuizen MG, de Waal Malefijt MC, van Riel PL, Pasker-de Jong PC, Laan RF. Change in bone mineral density in patients with rheumatoid arthritis during the first decade of the disease. Arthritis Rheum. 2001; 44(6):1254-1260. [PubMed: 11407683]

76. Hauser B, Riches PL, Wilson JF, Horne AE, Ralston SH. Prevalence and clinical prediction of osteoporosis in a contemporary cohort of patients with rheumatoid arthritis. Rheumatology (Oxford). 2014; 53(10):1759-1766. [PubMed: 24764264]

77. Hall GM, Spector TD, Delmas PD. Markers of bone metabolism in postmenopausal women with rheumatoid arthritis. Effects of corticosteroids and hormone replacement therapy. Arthritis Rheum. 1995; 38(7):902-906. [PubMed: 7612039]

78. Als OS, Riis BJ, Gotfredsen A, Christiansen C, Deftos LJ. Biochemical markers of bone turnover in rheumatoid arthritis. Relation to anti-inflammatory treatment, sex, and menopause. Acta Med. Scand. 1986; 219(2):209-213. [PubMed: 3485890]

79. Myasoedova E, Davis JM 3rd, Crowson CS, Gabriel SE. Epidemiology of rheumatoid arthritis: rheumatoid arthritis and mortality. Current Rheumatology Reports. 2010; 12(5):379-385. [PubMed: 20645137]

80. Meek IL, Vonkeman HE, van de Laar MA. Cardiovascular case fatality in rheumatoid arthritis is decreasing; first prospective analysis of a current low disease activity rheumatoid arthritis cohort and review of the literature. BMC Musculoskelet. Disord. 2014; 15:142. [PubMed: 24779371]

81. Kuller LH, Mackey RH, Walitt BT, et al. Determinants of mortality among postmenopausal women in the women's health initiative who report rheumatoid arthritis. Arthritis \& Rheumatology. 2014; 66(3):497-507. [Erratum appears in Arthritis Rheumatol. 2014 May;66(5)1394]. [PubMed: 24574208]

82. Solomon DH, Curhan GC, Rimm EB, Cannuscio CC, Karlson EW. Cardiovascular risk factors in women with and without rheumatoid arthritis. Arthritis Rheum. 2004; 50(11):3444-3449. [PubMed: 15529391]

83. Mackey RH, Kuller LH, Deane KD, et al. Rheumatoid Arthritis, Anti-Cyclic Citrullinated Peptide Positivity, and Cardiovascular Disease Risk in the Women's Health Initiative. Arthritis \& Rheumatology. 2015; 67(9):2311-2322. [PubMed: 25988241]

84. Park YB, Ahn CW, Choi HK, et al. Atherosclerosis in rheumatoid arthritis: morphologic evidence obtained by carotid ultrasound. Arthritis Rheum. 2002; 46(7):1714-1719. [PubMed: 12124853]

85. Inaba M, Tanaka K, Goto H, et al. Independent association of increased trunk fat with increased arterial stiffening in postmenopausal patients with rheumatoid arthritis. J. Rheumatol. 2007; 34(2): 290-295. [PubMed: 17304655]

86. Wright NC, Riggs GK, Lisse JR, Chen Z. Self-reported osteoarthritis, ethnicity, body mass index, and other associated risk factors in postmenopausal women-results from the Women's Health Initiative. Journal of the American Geriatrics Society. 2008 Sep; 56(9):1736-1743. [PubMed: 18662212] 
87. Multanen J, Heinonen A, Hakkinen A, et al. Bone and cartilage characteristics in postmenopausal women with mild knee radiographic osteoarthritis and those without radiographic osteoarthritis. Journal of musculoskeletal \& neuronal interactions. 2015 Mar; 15(1):69-77. [PubMed: 25730654]

88. Arden NK, Griffiths GO, Hart DJ, Doyle DV, Spector TD. The association between osteoarthritis and osteoporotic fracture: the Chingford Study. British journal of rheumatology. 1996 Dec; 35(12): 1299-1304. [PubMed: 9010060]

89. Arden NK, Crozier S, Smith H, et al. Knee pain, knee osteoarthritis, and the risk of fracture. Arthritis and rheumatism. 2006 Aug 15; 55(4):610-615. [PubMed: 16874784]

90. Smith TO, Higson E, Pearson M, Mansfield M. Is there an increased risk of falls and fractures in people with early diagnosed hip and knee osteoarthritis? Data from the Osteoarthritis Initiative. International journal of rheumatic diseases. 2016 May 6.

91. Vestergaard P, Rejnmark L, Mosekilde L. Osteoarthritis and risk of fractures. Calcified tissue international. 2009 Apr; 84(4):249-256. [PubMed: 19234808]

92. Martin-Millan M, Castaneda S. Estrogens, osteoarthritis and inflammation. Joint, bone, spine : revue du rhumatisme. $2013 \mathrm{Jul} ;$ 80(4):368-373.

93. Tinti L, Niccolini S, Lamboglia A, Pascarelli NA, Cervone R, Fioravanti A. Raloxifene protects cultured human chondrocytes from IL-1beta induced damage: a biochemical and morphological study. European journal of pharmacology. 2011 Nov 16; 670(1):67-73. [PubMed: 21920358]

94. Riancho JA, Garcia-Ibarbia C, Gravani A, et al. Common variations in estrogen-related genes are associated with severe large-joint osteoarthritis: a multicenter genetic and functional study. Osteoarthritis and cartilage / OARS, Osteoarthritis Research Society. 2010 Jul; 18(7):927-933.

95. Ma H, Wu W, Yang X, Liu J, Gong Y. Genetic effects of common polymorphisms in estrogen receptor alpha gene on osteoarthritis: a meta-analysis. International journal of clinical and experimental medicine. 2015; 8(8):13446-13454. [PubMed: 26550281]

96. Bay-Jensen AC, Tabassi NC, Sondergaard LV, et al. The response to oestrogen deprivation of the cartilage collagen degradation marker, CTX-II, is unique compared with other markers of collagen turnover. Arthritis research \& therapy. 2009; 11(1):R9. [PubMed: 20527083]

97. Lou C, Xiang G, Weng Q, et al. Menopause is associated with articular cartilage degeneration: a clinical study of knee joint in 860 women. Menopause (New York, N.Y.). 2016 Jun 20.

98. Tsai CL, Liu TK. Estradiol-induced knee osteoarthrosis in ovariectomized rabbits. Clinical orthopaedics and related research. 1993 Jun.(291):295-302.

99. Richette P, Dumontier MF, Francois M, et al. Dual effects of 17beta-oestradiol on interleukin 1beta-induced proteoglycan degradation in chondrocytes. Annals of the rheumatic diseases. 2004 Feb; 63(2):191-199. [PubMed: 14722210]

100. Gao W, Zeng C, Cai D, et al. Serum concentrations of selected endogenous estrogen and estrogen metabolites in pre- and post-menopausal Chinese women with osteoarthritis. Journal of endocrinological investigation. 2010 Oct; 33(9):644-649. [PubMed: 20339312]

101. Gao WL, Wu LS, Zi JH, et al. Measurement of serum estrogen and estrogen metabolites in preand postmenopausal women with osteoarthritis using high-performance liquid chromatographyelectrospray ionization-tandem mass spectrometry. Brazilian journal of medical and biological research $=$ Revista brasileira de pesquisas medicas e biologicas / Sociedade Brasileira de Biofisica ... [et al.]. 2015 Feb; 48(2):146-153.

102. Parazzini F. Progretto Menopausa Italia Study G. Menopausal status, hormone replacement therapy use and risk of self-reported physician-diagnosed osteoarthritis in women attending menopause clinics in Italy. Maturitas. 2003; 46(3):207-212. [PubMed: 14585523]

103. Von Muhlen D, Morton D, Von Muhlen CA, Barrett-Connor E. Postmenopausal estrogen and increased risk of clinical osteoarthritis at the hip, hand, and knee in older women. Journal of women's health \& gender-based medicine. 2002 Jul-Aug;11(6):511-518.

104. Nevitt MC, Cummings SR, Lane NE, et al. Association of estrogen replacement therapy with the risk of osteoarthritis of the hip in elderly white women. Study of Osteoporotic Fractures Research Group. Archives of internal medicine. 1996 Oct 14; 156(18):2073-2080. [PubMed: 8862099]

105. Hannan MT, Felson DT, Anderson JJ, Naimark A, Kannel WB. Estrogen use and radiographic osteoarthritis of the knee in women. The Framingham Osteoarthritis Study. Arthritis and rheumatism. 1990 Apr; 33(4):525-532. [PubMed: 2328031] 
106. Nevitt MC, Felson DT, Williams EN, Grady D. The effect of estrogen plus progestin on knee symptoms and related disability in postmenopausal women: The Heart and Estrogen/Progestin Replacement Study, a randomized, double-blind, placebo-controlled trial. Arthritis and rheumatism. 2001 Apr; 44(4):811-818. [PubMed: 11315920]

107. Spector TD, Nandra D, Hart DJ, Doyle DV. Is hormone replacement therapy protective for hand and knee osteoarthritis in women?: The Chingford Study. Annals of the rheumatic diseases. 1997 Jul; 56(7):432-434. [PubMed: 9486006]

108. Cirillo DJ, Wallace RB, Wu L, Yood RA. Effect of hormone therapy on risk of hip and knee joint replacement in the Women's Health Initiative. Arthritis and rheumatism. 2006 Oct; 54(10):31943204. [PubMed: 17009251]

109. Hussain SM, Cicuttini FM, Bell RJ, et al. Incidence of total knee and hip replacement for osteoarthritis in relation to circulating sex steroid hormone concentrations in women. Arthritis \& rheumatology (Hoboken, N.J.). 2014 Aug; 66(8):2144-2151.

110. Qin B, Wang J, Yang Z, et al. Epidemiology of primary Sjogren's syndrome: a systematic review and meta-analysis. Ann. Rheum. Dis. 2015; 74(11):1983-1989. [PubMed: 24938285]

111. Marchesoni D, Mozzanega B, De Sandre P, Romagnolo C, Gambari PF, Maggino T. Gynaecological aspects of primary Sjogren's syndrome. Eur. J. Obstet. Gynecol. Reprod. Biol. 1995; 63(1):49-53. [PubMed: 8674565]

112. Priori R, Minniti A, Derme M, et al. Quality of Sexual Life in Women with Primary Sjogren Syndrome. J. Rheumatol. 2015; 42(8):1427-1431. [PubMed: 26136488]

113. Taiym S, Haghighat N, Al-Hashimi I. A comparison of the hormone levels in patients with Sjogren's syndrome and healthy controls. Oral Surgery Oral Medicine Oral Pathology Oral Radiology \& Endodontics. 2004; 97(5):579-583.

114. Konttinen YT, Fuellen G, Bing Y, et al. Sex steroids in Sjogren's syndrome. J. Autoimmun. 2012; 39(1-2):49-56. [PubMed: 22300712]

115. Konttinen YT, Stegajev V, Al-Samadi A, Porola P, Hietanen J, Ainola M. Sjogren's syndome and extragonadal sex steroid formation: a clue to a better disease control? J. Steroid Biochem. Mol. Biol. 2015; 145:237-244. [PubMed: 25158020]

116. Porola P, Straub RH, Virkki LM, Konttinen YT, Nordstrom DC. Failure of oral DHEA treatment to increase local salivary androgen outputs of female patients with Sjogren's syndrome. Scand. J. Rheumatol. 2011; 40(5):387-390. [PubMed: 21877998]

117. Virkki LM, Porola P, Forsblad-d'Elia H, Valtysdottir S, Solovieva SA, Konttinen YT. Dehydroepiandrosterone (DHEA) substitution treatment for severe fatigue in DHEA-deficient patients with primary Sjogren's syndrome. Arthritis Care Res. 2010; 62(1):118-124.

118. Hartkamp A, Geenen R, Godaert GL, et al. Effect of dehydroepiandrosterone administration on fatigue, well-being, and functioning in women with primary Sjogren syndrome: a randomised controlled trial. Ann. Rheum. Dis. 2008; 67(1):91-97. [PubMed: 17545193]

119. Scorza R, Caronni M, Bazzi S, et al. Post-menopause is the main risk factor for developing isolated pulmonary hypertension in systemic sclerosis. Annals of the New York Academy of Sciences. 2002 Jun.966:238-246. [PubMed: 12114278]

120. Perkovic D, Martinovic Kaliterna D, Jurisic Z, Lalovac M, Radic M. Androgens in postmenopausal patients with systemic sclerosis. Rheumatology (Oxford). 2015 Apr; 54(4):744-746. [PubMed: 25524921]

121. Vinet E, Bernatsky S, Hudson M, Pineau CA, Baron M. Effect of menopause on the modified Rodnan skin score in systemic sclerosis. Arthritis research \& therapy. 2014; 16(3):R130. [PubMed: 24957704]

122. Beretta MC L, Origgi L, Ponti A, Santaniello A, Scorza R. Hormone replacement therapy may prevent the development of isolated pulmonary hypertension in patients with systemic sclerosis and limited cutaneous involvement. Scand Journal of Rheumatology. 2006; 35:468-471.

123. Marot M, Valery A, Esteve E, et al. Prevalence and predictive factors of osteoporosis in systemic sclerosis patients: a case-control study. Oncotarget. 2015; 6(17):14865-14873. [PubMed: 25944694] 
124. La Montagna G, Vatti M, Valentini G, Tirri G. Osteopenia in systemic sclerosis. Evidence of a participating role of earlier menopause. Clinical rheumatology. 1991 Mar; 10(1):18-22. [PubMed: 2065501]

125. Kocak M, Basar MM, Vahapoglu G, Mert HC, Gungor S. The effect of Behcet's disease on sexual function and psychiatric status of premenopausal women. J. Sex. Med. 2009; 6(5):1341-1348. [PubMed: 19040624]

126. Yetkin DO, Celik O, Hatemi G, Kadioglu P. Sexual dysfunction and depression in premenopausal women with mucocutaneous Behcet's disease. Int. J. Rheum. Dis. 2013; 16(4):463-468. [PubMed: 23992269]

127. Henes M, Froeschlin J, Taran FA, et al. Ovarian reserve alterations in premenopausal women with chronic inflammatory rheumatic diseases: impact of rheumatoid arthritis, Behcet's disease and spondyloarthritis on anti-Mullerian hormone levels. Rheumatology (Oxford). 2015; 54(9):1709_ 1712. [PubMed: 25957439]

128. de Andrade DC, de Magalhaes Souza SC, de Carvalho JF, et al. High frequency of osteoporosis and fractures in women with dermatomyositis/polymyositis. Rheumatol. Int. 2012; 32(6):15491553. [PubMed: 21327426] 


\section{Key Points}

1. Menopause, and its treatment, may affect rheumatic diseases; and rheumatic diseases may affect menopause.

2. Treatment with cyclophosphamide, especially at an older age, may induce menopause.

3. Decreased ovarian reserve is a feature intrinsic to disease notwithstanding treatment.

4. Osteoporosis is common in several rheumatic diseases, and menopause increases the risk of osteoporosis as well as fragility fracture.

5. The effect of menopause and its treatment is difficult to define in osteoarthritis because of contradictory results. 
Table 1

Effect of post-menopausal hormone replacement on osteoarthritis

\begin{tabular}{|c|c|c|c|c|}
\hline Study & Type of study & Population & Results & \\
\hline WHI (86) & $\begin{array}{l}\text { Observational } \\
\text { study }\end{array}$ & $\begin{array}{l}\mathrm{N}=146,494 \text { post- } \\
\text { menopausal } \\
\text { women }\end{array}$ & • & $\begin{array}{l}\text { HRT use associated with increased odds of OA. } \\
29 \% \text { increase odds of OA with current use and } 38 \% \text { with past use } \\
\text { of HRT. }\end{array}$ \\
\hline Parazzini F (102) & $\begin{array}{l}\text { Cross sectional } \\
\text { study }\end{array}$ & $\begin{array}{l}\mathrm{N}=42,464 \text { Italian } \\
\text { postmenopausal } \\
\text { women }\end{array}$ & $\begin{array}{l}\cdot \\
\cdot \\
\cdot \\
\cdot\end{array}$ & $\begin{array}{l}\text { Increase odds of OA with menopause } \\
\text { Natural menopause associated with increased OR of } 1.13 \text { for OA } \\
\text { (95\% CI 1.07, 1.21) } \\
\text { Surgical menopause OR of } 1.18 \text { for OA ( } 95 \% \text { CI } 1.09,1.28) \\
\text { HRT: } 27 \% \text { lower odds of physician diagnosed OA compared to } \\
\text { those not on HRT. }\end{array}$ \\
\hline Von Muehen (103) & Cross sectional & $\begin{array}{l}\mathrm{N}=1001 \text { post- } \\
\text { menopausal } \\
\text { women }\end{array}$ & • & $\begin{array}{l}\text { Post-menopausal estrogen use: } 34 \% \text { higher prevalence of OA } \\
\text { compared to non-users. } \\
\text { Higher prevalence of hip and hand OA I subjects using estrogen } \\
\text { replacement therapy compared to non-users }(15.8 \% \text { compared to } \\
13.5 \%, p=0.02 \text { for hip, } 4.1 \% \text { compared to } 1.1 \%, p=0.002) \text {. }\end{array}$ \\
\hline Nevitt (104) & $\begin{array}{l}\text { Cross sectional } \\
\text { study }\end{array}$ & $\begin{array}{l}\mathrm{N}=4366 \text { post- } \\
\text { menopausal } \\
\text { women }\end{array}$ & • & $\begin{array}{l}40 \% \text { lower prevalence for radiologic and symptomatic OA of hip } \\
\text { with estrogen use. }\end{array}$ \\
\hline $\begin{array}{l}\text { Framingham OA } \\
\text { study (105) }\end{array}$ & Cohort Study & $\mathrm{N}=831$ & $\bullet$ & $\begin{array}{l}\text { Non-significant protective effect for radiographic knee OA (OR } \\
0.71,95 \% \text { CI } 0.42,1.20 \text { ) or severe radiographic OA (OR } 0.66 \text {, } \\
95 \% \text { CI } 0.33,1.32) \text { with estrogen use. }\end{array}$ \\
\hline $\begin{array}{l}\text { Heart } \\
\text { Estrogen/Progestin } \\
\text { replacement study } \\
(106)\end{array}$ & $\begin{array}{l}\text { Randomized } \\
\text { control trial }\end{array}$ & $\begin{array}{l}\mathrm{N}=969 \text { post- } \\
\text { menopausal } \\
\text { women }\end{array}$ & $\bullet$ & $\begin{array}{l}\text { No difference between women on HRT vs. placebo on knee pain } \\
\text { and related disability. }\end{array}$ \\
\hline $\begin{array}{l}\text { Chingford Study } \\
\text { (107) }\end{array}$ & $\begin{array}{l}\text { Cross sectional } \\
\text { study }\end{array}$ & $\begin{array}{l}\mathrm{N}=606 \text { post- } \\
\text { menopausal } \\
\text { women }\end{array}$ & • & $\begin{array}{l}\text { Current HRT use was protective for knee OA (OR } 0.31,95 \% \text { CI } \\
0.11,0.93 \text { ) } \\
\text { Non-significant protective effect for OA of DIP joint with HRT } \\
\text { use; OR } 0.48 \text { ( } 95 \% \text { CI } 0.17,1.42 \text { ) } \\
\text { No effect on carpometacarpal joint. (OR } 0.94,95 \% \text { CI } 0.44,2.03 \text { ) }\end{array}$ \\
\hline
\end{tabular}

